
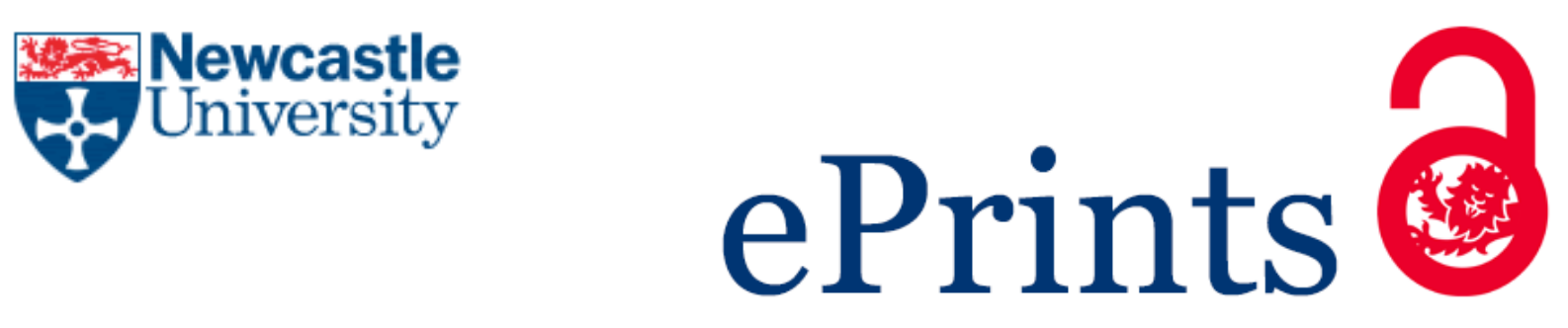

Jones FR.

Partisanship or Loyalty? Seeking Textual Traces of Poetry Translators'

Ideologies.

Translation and Literature 2016, 25(1), 58-83.

\title{
Copyright:
}

This is the author's accepted manuscript of an article that has been published in its final, definitive form by Edinburgh University Press, 2016.

DOI link to article:

http://dx.doi.org/10.3366/tal.2016.0237

Date deposited:

$24 / 01 / 2016$

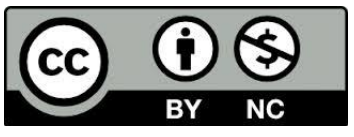

This work is licensed under a Creative Commons Attribution-NonCommercial 3.0 Unported License 


\title{
Partisanship or Loyalty? \\ Seeking Textual Traces of Poetry Translators' Ideologies
}

\author{
Francis R. Jones
}

Author's pre-publication draft.

Published in: Translation and Literature, 25 (2016), 58-83, ( ) Edinburgh University Press.

The wish to investigate my subject here, translator partisanship, was prompted by earlier surveys which I authored or co-authored of recently published 'translation projects' (books, paper and web journals, blogs, web forum postings) containing English translations of Bosnian and Serbian poetry. These surveys explored how 'structural' aspects of projects can communicate the ideological stance of those involved: translators, source poets, editors and web-posters, for example. ${ }^{1}$ Specifically, book/website titles, selection of poems used, 'paratexts' such as translators' introductions, and the 'positionalities' (geographic origins and allegiances) $)^{2}$ of team members, often revealed or explicitly promoted the team's attitude towards the physical conflicts and the cultural-political debates before, during, and after Yugoslavia's breakup from 1991 onwards.

As used in these surveys, the idea of 'ideology' follows Verschueren's definition: any normative belief-system about social reality that a community regards as 'commonsensical', 3 with 'community' defined as any social grouping (e.g. 1990s Serbian dissident writers). Thus political 'ideologies' might encompass both blood-and-soil 'ethno-nationalism', based on the primacy of one's own ethnos, and the opposing 'cosmopolitanist' belief that 'one's primary moral obligations are directed to all human beings ... and political arrangements should faithfully reflect this'. ${ }^{4}$ Ideology also extends beyond politics proper, to a belief in gender equality, say, or the belief that the community's poetry is a good that would enrich the lives of readers worldwide.

Since they focused on structural features, these surveys did not examine how far poetry translators' 'textual' (i.e. semantic and stylistic) decisions while actually translating might also communicate ideological stances. The present study addresses this by analysing translation 'shifts' in poems from forty-three of the Serbian-to-English projects previously surveyed. 'Shifts' are translators' decisions to alter or remove semantic and stylistic features when translating, or to add new features. It is assumed that these may potentially combine to change the 'macrotextual' messages that readers gain from the text. ${ }^{5}$ Of particular interest here, of course, are what might be called 'ideologizing shifts': shifts which consciously or

\footnotetext{
${ }^{1}$ Francis R. Jones, 'Poetry Translation, Nationalism, and the Wars of the Yugoslav Transition', The Translator, 16 (2010), 223-53. See also Francis R. Jones and Damir Arsenijević, '(Re)constructing Bosnia: Ideologies and Agents in Poetry Translating', in Translation and the Construction of Identity, edited by Juliane House, M. Rosario Martín Ruano, and Nicole Baumgarten (Seoul, 2005), pp. 68-95; Francis R. Jones, Poetry Translating as Expert Action: Processes, Priorities, and Networks (Amsterdam, 2011), Ch. 3.

2 I take the term from Gideon Toury, In Search of a Theory of Translation (Tel Aviv, 1980).

3 Jef Verschueren, Ideology in Language Use (Cambridge, 2012), p. 10.

4 For 'ethno-nationalism' and 'cosmopolitanism', respectively, see John Hutchinson and Anthony D. Smith, 'Introduction', in Nationalism, edited by Hutchinson and Smith (Oxford, 1994), pp. 4, 5, 11; Stanford Encyclopedia of Philosophy <http://plato.stanford.edu/entries/nationalism/> (accessed 27 July 2015).

5 Here I follow the principles (though not the complex taxonomy) in Kitty Van Leuven-Zwart, 'Translation and Original: Similarities and Dissimilarities, Part I', Target, 1 (1989), 151-81; 'Part II', Target, 2 (1990), 69-95.
} 
unwittingly change, downplay, or intensify an ideological element in the source poem, and/or introduce a new ideological message. This analysis enables three interrelated questions to be addressed:

1. Does textual ideologizing in poetry translation appear to be a marginal or widespread phenomenon?

2. What factors might enable it and/or hinder it?

3. How does the resulting picture relate to earlier findings about links between ideology and structural aspects of poetry translation projects?

These questions are worth asking, because the answers are not obvious. Studies show that ideologizing shifts can indeed occur, not least because literary translation typically involves open-ended decisions that may deliberately or unwittingly reveal the translator's beliefs and attitudes. ${ }^{6}$ Nevertheless, other studies report that most recent poetry translators try to give a 'reliable representation' of the source poem, operating with a collective norm, and thus an ethic, which would discourage changes deriving from the translator's ideological stance. ${ }^{7}$ What is not known, and what this study investigates, is the relative strength of these two opposing pulls, and how they interact.

Links between translation and ideology might well be most visible if the context of translation is ideologically sensitive - another reason for using the same dataset as previously. ${ }^{8}$ This comprised 126 print and web translation projects, published between 1992 and 2008, and containing English translations of poetry by Bosnian-Herzegovinan (henceforth 'Bosnian' for short) and Serbian poets. For reasons of time and resources, the present study restricts itself to the analysis of forty-three of the Serbian translations. Its timeframe spans the breakup of Yugoslavia and the emergence of its successor states, such as Serbia and Bosnia - a context marked by military conflict, political change, and fierce debates about community, identity, and socio-political power. However, some source poems and translations in this corpus were first published in the nineteenth or early-to-mid-twentieth century, and some paratexts refer to those periods. Hence the following paragraphs sketch the long-term historical background as well as recent events and debates in this region, with special reference to Serbia.

The concept of narod ('nation', in the sense of ethnos or 'imagined community') is central to (post-)Yugoslav politics. Thus the 1974 Yugoslav Socialist Federal constitution formalized the fact that component republike (Serbia, Bosnia, and so on) contained people from various nations - such as 'Muslims' (later known as Bosniaks), Serbs, and Croats in Bosnia. During the 1930s and '40s, and again from the 1980s onward, the concept also formed the basis of rival ethno-nationalist political agendas. Several were 'pernicious' (i.e. the rights claimed for the narod were denied to other narodi in the same space), aiming to

\footnotetext{
6 Examples of such studies include Román Álvarez and M. Carmen-África Vidal, 'Translating: A Political Act', in Translation, Power, Subversion, edited by Álvarez and Vidal (Clevedon, 1996), pp. 1-9; Tarek Shamma, 'The Exotic Dimension of Foreignizing Strategies', The Translator, 11 (2005), 51-67; and several studies collected in Translation, History and Culture, edited by Susan Bassnett and André Lefevere (London, 1990); Translation and Power, edited by Maria Tymoczko and Edwin Gentzler (Amherst, MA, 2002); Apropos of Ideology, edited by Calzada Pérez (Manchester, 2003).

7 Jones, Poetry Translating as Expert Action, p. 179. For norms as ethics, see Andrew Chesterman, Memes of Translation (Amsterdam, 1997), p. 172.

8 In Jones, 'Poetry Translation, Nationalism'.
} 
establish a single-narod dominated state from formerly mixed-narod territories. ${ }^{9}$

The languages now known as Serbian, Croatian, and Bosnian are mutually comprehensible, and in socialist Yugoslavia were officially regarded as one multi-variety language (Serbo-Croatian). Hence, for Serbs, narod is conceptualized largely along religiocultural lines, with their Orthodox Christian Balkan heritage distinguishing them from the Croats and Bosniaks (Central European Catholic and Balkan Muslim heritage respectively). Language, however, adds an extra distinction between Serbia's Serbian-narod majority and its largest Hungarian- and Albanian-speaking minorities (also with Catholic and Muslim heritages respectively).

The medieval kingdoms of Serbia and Bosnia were conquered by Ottoman Turkey during the late Middle Ages; that of Croatia gradually came under Austro-Hungarian rule. In the late eighteenth and nineteenth centuries, extemporized bardic epics recorded in these regions drew the attention of a Europe-wide readership enthused by Ossian and Scott. ${ }^{10}$ They also laid an intellectual basis for a standard Serbo-Croatian language and, ultimately, a jugoslavenska ('south-Slav') state incorporating Serbia (independent since the 1830s) and other narodi still under Ottoman and Austro-Hungarian rule. Serbia was allied to Britain, France, and Russia in World War I, and though its armies succumbed disastrously to forces of the Central Powers in 1915, it emerged on the victorious side. The kingdom of Yugoslavia was formed in the treaties that followed. In the 1930s, however, inter-narod tensions worsened, especially between Serbia and Croatia. After the Nazi invasion of 1941, Yugoslavia was partitioned between Germany and its allies; a fascist puppet regime in Croatia became particularly notorious for mass killings of non-Croats, especially Serbs and Jews. Tito's Communist partisans, who took over the reborn Yugoslav state in 1945, restored inter-narod unity under an increasingly federal rather than centralist constitution.

After Tito's death, and with the crumbling of state socialism across Eastern Europe in the 1980s, ethno-nationalist politics re-emerged, and were a key factor in Yugoslavia's breakup. Serbia, the largest republika, was ruled by Slobodan Milošević's ethno-nationalist regime from roughly 1988 to 2000. From 1991 on, as other republike seceded from the Yugoslav Federation, the Milošević regime increasingly dominated its remnants - embarking on war with breakaway Slovenia and Croatia (1991-2), sponsoring a brutal Serbian-narod uprising in newly-independent Bosnia (1992-5), and repressing the civil rights of Albanians in Serbia's southern province of Kosovo. Here, overt aims of preventing secession, and of protecting Serbian-narod minorities in Croatia, Bosnia, and Kosovo, overlay a covert aim of carving out a largely mono-ethnic 'Greater Serbia' from the ruins of Yugoslavia, often by means of ethnic cleansing. Virtually all these aims failed. NATO-backed military campaigns by the Croatian and Bosnian governments (1995) and Kosovar Albanian rebels (1999) led to mass expulsions and migrations of Serbs from Croatia and Kosovo. Kosovo, under Albanianmajority rule, has declared independence. This status is recognized by 108 of the 193 UN states, Serbia not included. Outside Serbia proper, only the para-state of Bosnia's Republika Srpska remains under Serbian control.

In 1990s Serbia, as in other post-Yugoslav states, the political dominance of ethnonationalism concealed a 'culture war' between ethno-nationalist and cosmopolitanist outlooks. This reflected a divide among Serbia's intellectuals between those who sided with the ruling ethno-nationalist politics and a dissident opposition. Popular protest against

9 For imagined community (where a sense of fellowship is mentally constructed rather than physically grounded) and pernicious nationalism, respectively, see Benedict Anderson, Imagined Communities: Reflections on the Origin and Spread of Nationalism (London, 1999); Stanford Encyclopedia of Philosophy (n. 4).

10 The Bosnian-Dalmatian epic Hasanaginica, for instance, prompted twenty-two translations between 1774 and 1841 - including versions by Goethe, Pushkin, and Scott himself. See Alija Isaković, 'Reč čitaocu', in Hasanaginica, edited by Alija Isaković (Sarajevo, 1975), pp. 7-8. 
Milošević's policies and/or their failure gradually grew, however, leading to his overthrow in 2000. During the 2000s, Serbian politics was split between the cosmopolitanist, EU-oriented demokrati, and the ethno-nationalist radikali - though with the latter, a more managerial wing has recently been distancing itself from its hard-right roots.

In the region today, a key political divide sets the wish (especially among Serbs) to move on from the 1990s wars against the view (especially among Bosniaks) that this can only be done if war crimes are acknowledged by their perpetrators. Nevertheless, there is a widely felt desire to escape from the Balkanist 'warring tribes' stereotyping that has characterized many outsiders' views of the region (as well as, for many Serbs, to escape from Serbia's pariah-state stereotype deriving from Milošević's policies), and to be regarded as citizens of normal European states. ${ }^{11}$ Other debates explore how pride in Balkan heritage might co-exist with a sense of European citizenship, and set traditional patriarchal and heterosexist systems against egalitarian models of social relations. Cultural products, including poetry, are often enlisted into these debates. For instance, bardic epics about the 1389 Battle of Kosovo, in which the Serbian kingdom fell to the Ottoman Turks, form a central element in Serbianethno-nationalist narratives of cultural particularism and Serbia as bulwark of Christendom.

Researchers are inevitably implicated in what they research. Not least in settings of socio-political conflict, all research has a point of view. Mine is that of a translator of Serbian and Bosnian poetry into English whose ideological stances (as defined above) involve a belief in the value of the region's poetic culture, but also in promoting a cosmopolitanist socio-political agenda. ${ }^{12}$ Hence my translations appear in five of the projects analysed here. My point of view also inevitably underlies the socio-historical outline above and the interpretations below. To keep this visible, I use the first person for myself as researcher and translator, and whenever I base conclusions on my insights as a translator, I make this explicit.

This study examines translation projects. These are team enterprises: poetry translators rarely operate solo. Most projects also involve a publisher, and often an editor and/or a living source poet. Some involve several translators and several poets. An editor, web forum poster, or source poet may hold more power than the translator in selecting and presenting texts; and sometimes (as with the web-posting of older translations) the translator may not even be part of the team. The main responsibility for target-poem textuality, however, usually lies with translators. Editors rarely intervene. If a living source poet (as often happens with English) can read the target language, s/he may advise the translator, and occasionally co-translate with or even try to overrule the translator. Nevertheless, as reports on translator-poet relations are lacking for most projects in this study, I assume henceforth that textual decisions are the translator's.

As for team positionality, poetry translation from a 'dominated', non-globalized, to a 'dominant', globalized language (Serbian to English, say), is not necessarily controlled by target community-oriented players, such as target-country publishers. A project may be controlled by source community-oriented players, who wish to use the dominant language to give an international voice to the source community's writers and values, including culturalpolitical standpoints. ${ }^{13}$ These players may be editors or blog/forum posters. They may also be

11 For 'Balkanist' narratives of south-eastern Europe as the West's chaotic other, see Maria Todorova, Imagining the Balkans (New York, 1997).

12 Outlined, for example, in my 'Introduction' to one of the projects analysed here: Ivan V. Lalić, Fading Contact, translated by Francis R. Jones (London, 1997), pp. 9-17.

13 I draw here on Pascale Casanova, 'Consecration and Accumulation of Literary Capital: Translation as Unequal Exchange', translated by Siobhan Brownlie, in Critical Readings in Translation Studies, edited by Mona Baker (London, 2010), p. 288. This counters the assumption underlying Lawrence Venuti's 
translators, be they target-language natives with a strong allegiance to the source community and culture, or source-language natives, including émigrés in target-language countries.

Literary translation typically communicates works of social value from one community, and the culture(s) with which its members identify, to another. Hence, as many scholars claim, it is often bound up with the sociopolitics of intercultural exchange: for instance, using a web archive in English, the world's most globalized language, to promote Serbian poetry internationally. More particularly, literary translation is often regarded as bound up with the translators' cultural and ideological affiliations - although, as the above discussion suggests, other project team members should be included with translators.

These affiliations may be communicated, first, by the selection of poems or poets made for a project. Second, such features as a project's title or the name of a web project's host website can create expectations about its purpose. Third, paratextual presentation, especially prefaces and commentaries, can steer readers towards interpretations that may reflect an ideological standpoint. Fourth, the positionalities of key players in the project team, especially in contexts dominated by discourses of ethnicity and territory (as in this study), may also show the team's ideological stance. Earlier analyses of the Bosnian+Serbian survey confirmed how these 'structural' features can reveal the team's ideological affiliation. For instance, in a 1997 special issue of the Serbian literary journal Pro Femina, a 'dissident plurality' centred around gender is signalled by the journal's title, highlighted by an editor's introduction, and is underlined by the project's trans-national and cross-gender positionality, involving four female Serbian and four male 'Anglo' (English-native-user) translators including myself. It is also promoted by the selection of poems by female poets, privileging a female or a dissident viewpoint. On the other hand, an example of an ethno-nationalist standpoint is a posting of a translation of an epic about the Battle of Kosovo on a white supremacist web forum by a single Serbian contributor, whose avatar is 'Racial Socialist'. ${ }^{14}$ Even presenting Serbian works as 'simply poetry' (the commonest team stance) is arguably not ideologically neutral, because it promotes by implication a view of Serbian culture that ignores, or refuses to be stereotyped by, the 1990s conflicts and human rights violations.

A frequent claim, which nonetheless deserves more detailed examination, is that the team's, and especially the translator's, ideological stance will also be expressed textually, i.e. stylistically and semantically. Thus Venuti argues that literary translators' stylistic preferences within translated texts reveal their stance towards intercultural power relations. And several studies show how the use of archaisms, vernacular, or dialect in translation, as against standard contemporary language, can suggest a cultural or ideological point of view. My decision as a translator, for instance, to use Chaucerian English to recreate a modern Bosnian poet's use of medieval Bosnian was informed by a wish to support the poet's grounding of a pan-Bosnian identity in a medieval past common to all narodi. ${ }^{15}$ Similarly, Tymoczko argues that ideological stances can be revealed in translators' semantic choices. She sees translators as 'partial', in both senses of the term: because translators can only translate part of the meanings within each text, and because the features of the target language might lead them to add meanings, their partisanship is manifested in which

domestication-foreignization thesis, that translation policy is largely determined by target-culture agents, in The Translator's Invisibility: A History of Translation, 2nd edn (London, 2012).

14 'Serbian Epic Poetry', 'Stormfront.org' (2003), post \#1 <http://www.stormfront.org/forum/showthread.php?s=d9040617502c2b57caa011fda8ffb341\&t=103123> (accessed 4 August 2015)

15 Venuti, The Translator's Invisibility; Simo K. Määttä, 'Dialect and Point of View: The Ideology of Translation in the Sound and the Fury in French', Target, 16 (2004), 319-39; Francis R. Jones, 'The Poet and the Ambassador: Communicating Mak Dizdar's Stone Sleeper', T\&L, 9 (2000), 65-87. 
meanings they choose to convey. ${ }^{16}$ Many studies have shown that this can occur; indeed, it is virtually a given in recent scholarship on literary translation that textual shifts can reveal the translator's point of view ${ }^{17}$ - but virtually all, to my knowledge, are case studies examining the works of one source author or a handful of source authors, typically with the aim of illustrating translators' partisanship. Case studies are invaluable in exploring the why and how of phenomena, but they cannot show how typical phenomena are. This makes it risky to base theoretical claims on a group of case studies - especially as this group might be dominated by 'untypical but interesting' cases rather than by cases which simply repeat the typical.

Norm-based approaches to translation, by contrast, focus on capturing the typical. Chesterman's 'relation norm' shows how translators typically aim to keep an 'appropriate relation of relevant similarity ... between the source [and] target text'. ${ }^{18}$ 'Relevant similarity', for most modern-day poetry translators, implies similarity in semantics, but also in style and poetics. This appears at first sight to allow little space for ideology-based changes. Another norm, however, is that the translation should function as a target-culture poem. With free verse source poems, these demands rarely conflict. Except when wordplay is present, making a semantically and stylistically close rendering that functions as a target-culture poem in free verse is not in principle problematic. When source-poem effects include metric patterning, rhyme or wordplay, however, translators have to compromise. Most translators seem willing to deviate slightly from source semantics by using 'creative adaptations' (changes of meaning within a semantic field, e.g., 'happiness' to 'bliss') to recreate stylistic and poetic effects. If this does not work, some translators abandon form and/or style, converting, say, a poem using metre and rhyme to a semantically close free verse composition. Others retain such effects by using 'creative transformations' (e.g. with 'coal-dust enters the vocal chords', changing 'enters' to 'numbs'). These abandon exact meaning, the translator being guided instead by interpretation of the source poem's underlying purpose, imagery, etc. ${ }^{19}$ The compromises involved in translating poems rich in stylistic or poetic effects, therefore, may allow a space for ideologizing changes.

The tension between textual ideologizing and relevant similarity can also be viewed inter-personally. Nord describes translation as a communication act constrained by the translator's 'loyalty' to three 'partners': commissioning agent, source writer, and target reader. ${ }^{20}$ When translation explicitly re-communicates a foreign-language text, which is virtually always the case with poetry, partners judge the act according to their 'subjective theory' of communication - which, for readers, would be that a translated poem reliably represents its source. Loyalty to source poet and target readers, therefore, would pull translators towards close recreation of semantics, but also of style and poetic effects. In poetry, the commissioner (if separate from the source poet) is typically a publisher or editor who, in a team-based model of translation production, is usually the most powerful player, with most influence over the project's aims. If these have a strong ideological element, loyalty to the commissioner may pull translators towards ideologizing, unless the team's aims are better expressed by close re-creation - if the source poem already expresses the team's

16 Maria Tymoczko, 'Translation and Political Engagement: Activism, Social Change, and the Role of Translation in Geopolitical Shifts', The Translator, 6 (2000), 23-47 (p. 23).

17 For a general discussion of this viewpoint, see Maria Tymoczko, 'Translation: Ethics, Ideology, Action', Massachusetts Review, 47 (2006), 442-61.

18 Chesterman (n. 7), p. 69.

19 Jones, Poetry Translating as Expert Action, pp. 102-03, 179-80.

20 Christiane Nord, 'Loyalty Revisited: Bible Translation as a Case in Point', The Translator, 7 (2001), 185202. 
ideology, for instance.

The present study, therefore, explores this tension between textual ideologizing and relevant similarity. Its methods are based on the premise that only a relatively large database of poetry translations can adequately indicate the extent of textual ideologizing, and how it might be enabled or constrained. As already noted, it used the seventy Serbian projects from the 2010 survey as its initial pool of cases, omitting the fifty-six Bosnian projects. The former, gathered in 2009, comprised all the projects I could find which appeared between 1992 and 2008, and which contained at least one whole poem, in English translation, by a poet identified as Serbian. Most projects, both print (identified in online bibliographies, on publishers' websites, etc) and web-based, were found via Google and Yahoo! web searches. Other print projects were identified in academic bibliographies (via the FirstSearch portal), UNESCO's Index Translationum database, and a 2006 survey. ${ }^{21}$ Bibliographic data plus poets' and translators' details were logged for each project on a spreadsheet, along with one or more keyword tags reflecting signals given by its title, its paratexts, and the poems' content (where available): thus Pro Femina's title, for instance, was tagged 'women/feminist'. These tags were then grouped by similarity into three loose categories:

1. Political debates and conflicts: 'identity-local' and 'patriotism' (both without ethno-nationalist overtones), 'ethno-nationalism', 'cosmopolitanism' (including opposition to ethno-nationalist war), 'war-1990s', ['politics' (other aspects)] ${ }^{22}$

2. Social/cultural background: 'cultural-history' (e.g. bardic epics), 'place-local' and 'place-Balkans' (non-politicized sense of place), 'post-war' (aftermath of the 1990s conflicts), ['war-WWII'], ['religion'], ['place-Yugoslavia'], ['women/feminist']

3. Poetry-as-literature: 'poems', 'poet(s)', ['translation'], ['language'], 'miscellaneous' (all topics not mentioned above, e.g. love, nature, urban life, anomie, time)

These structural data give a framework for the present textual study.

When gathering textual data in 2013 and 2014, I could not find target poems for all seventy projects: some web projects had gone offline, and several paper projects published in the USA and Serbia were not obtainable in the UK. Other projects were excluded because source poems were not obtainable. The remaining 47 projects contained 2,154 target poems. After excluding duplications of poems across multiple projects, and projects containing only duplicate poems, 43 'unique' projects were left, containing 1,941 unique poems. These were too many poems to analyse. However, initial explorations showed that establishing rigorous sampling procedures would be problematic. Firstly, projects varied widely according to:

- $\quad$ poem-count, from 1 to 375;

- $\quad$ poet-count, from 1 to 72 ;

- translator-count, from 1 to 44 (including the same translator translating multiple poets, and the same poet translated by multiple translators);

- $\quad$ translator output, from 1 to 119 poems per translator;

- $\quad$ poem length, from 4 to 2,819 lines.

21 Snezana Zabic and Paula Kamenish, 'A Survey of Bosnian, Croatian, and Serbian Poetry in English Translation in the U.S. and Canada', CLCWeb: Comparative Literature and Culture, 8 (2006), article 5 $<$ http://docs.lib.purdue.edu/clcweb/vol8/iss3/5/> (accessed 4 August 2015)

22 Square brackets denote low-frequency keywords not analysed in the 2010 article. 
This, plus the fact that some translators, poets, and poems appeared in multiple projects, gave no single sampling criterion: gathering a fixed number of poems per project, for instance, would have under-reported the larger multi-translator and multi-poet anthologies. Secondly, source poems were sometimes hard to find, and search time was multiplied by the number of source poets in a project - making it unfeasible to trace work by all seventy-two poets in Miloslav Šutić's Anthology of Modern Serbian Lyrical Poetry: 1920-1995, for instance. ${ }^{23}$ Sampling was helped, however, by a third early realization: that each translator's stylistic and semantic 'approaches' are very consistent across different poems and source poets (for instance, Charles Simic's many translations are semantically close to their source texts but with occasional omissions). ${ }^{24}$

Hence a largely purposive (researcher-directed) sampling policy was adopted. Sample poems were analysed from all 43 unique projects (with long poems, 35-line extracts only were analysed). With each multi-poem project, at least two poems were randomly chosen where enough source poems were available. With multi-translator projects, in order to sample work by different translators, more poems were chosen where possible. Also, if a project contained both fixed-form and free-verse target poems, both were sampled where available, to explore whether creative changes driven by fixed-form translations might enable textual ideologizing. Altogether, 2,780 lines from 143 poems (7\% of unique poems) were analysed: up to 13 poems per project, though with most projects just one or two poems were selected (because they contained just one or two poems, or because of the constraints mentioned above). These involved 50 named translators and 44 named source poets in various combinations, plus an unknown number of anonymous translators and folk poets. This is a sizeable dataset, though fuzzy sampling methods mean that quantitative findings should be seen as broad-brush rather than precise indicators of tendencies.

Textual analysis firstly involved mapping semantic shifts. To exclude excess lowlevel detail, this focused largely on lexical items common to both languages, i.e. noun, verb and adjective stems, adverbs, conjunctions, and prepositions. Grammatical morphemes and particles (non-lexicalized in one or both languages) were excluded, though verb person and genitive relations were inspected. Target poems were marked up as follows:

- $\quad$ Additions: items absent in the source but present in the target poem;

- $\quad$ [Deletions]: items present in the source but absent in the target poem;

- $\quad$ Alterations [from source item]: items whose meaning changes away from equivalents given in a bilingual dictionary.

'Retentions', which keep dictionary equivalents, were left unmarked, as were items excluded from analysis.

Markup procedure is illustrated by the opening lines of 'Morska vrba', a sonnet by Jovan Dučić (1871-1943), with its translation, 'A willow by the sea':25

Sama vrba stoji nad morem, vrh sveta,

Rasplela je kosu zelenu i dugu.

23 Miloslav Šutić, Anthology of Modern Serbian Lyrical Poetry: 1920-1995 (Belgrade, 1999).

24 E.g. The Horse Has Six Legs: An Anthology of Serbian Poetry, edited and translated by Charles Simic (St Paul, MN, 1992).

25 'Songs of the Sun, and of Love and Death, by Jovan Dučić, publisher's webpage, Serbian Classics Press (2008) <http://www.serbianclassics.com/serbian-poetry/jovan-ducic.html> (accessed 4 August 2015). Because the full book could not be consulted, it was not possible to identify which of its eight translators was responsible for this poem. 
Literal gloss

A/the lone willow stands above the sea, top of the world,

It/she has unravelled its/her hair long and green.

\section{Published translation}

The top of the world is a willow by the sea,

Its plaited leaves are long, green, fanned.

\section{Mark-up}

The top of the world is [stands] a [lone] willow by [above] the sea,

Its plaited leaves [hair] are [unravel] long, [and] green, fanned.

Line 2's mark-up, for instance, shows the addition of plaited, the alteration of [hair] to leaves, and the deletion of [and]. The change from 'has unravelled' to are is marked as a verb-stem alteration (are [unravel]), but the tense-change is not marked. ${ }^{26}$

Style was analysed by noting any source-target changes along axes for formalinformal, regional-standard, idiosyncratic-normalizing, and archaizing-modernizing. The example below comes from the bardic epic Lov Markov s Turcima (featuring Marko Kraljević, mythic hero and unruly Christian vassal of the Turkish sultan), in David Halyburton Low's 1922 translation 'Marko's hunting with the Turks'. ${ }^{27}$ This was marked as 'archaizing', because it uses pre-contemporary forms such as spake, whereas the source uses a folk style that is not in itself pre-contemporary:

Tad govori Kraljeviću Marko:

'Je li testir, Murate vezire,

da ja pustim mojega sokola

da uhvati utvu zlatokrilu?'

Veli njemu Murate vezire.

Then spake Kraljević Marko:

'Is it permitted, Murad Vizier,

That I loose now my falcon,

For to take yonder duck of golden wing?'

Quoth [to him] Murad the Vizier.

Source- and target-poem form was also logged on the spreadsheet: for the above example, 'deseterac' (the bardic four+six syllable line) plus 'free verse' respectively.

The shifts were then checked for evidence of ideologizing, i.e. heightening, lowering, or changing the source poem's ideological signals, or adding different ones. This inevitably involved subjective decisions; in borderline cases, I erred on the side of classifying as 'ideologized', in order to mark a wider range of practices for later qualitative analysis. Ideologized translations were also tagged with relevant ideology-type(s): most tags are listed under the keywords above (e.g., 'ethno-nationalism', 'religion'), with the additions of 'orientalism' and 'royalism'.

The two last-cited examples were not marked as ideologized. 'A willow by the sea' contains many semantic changes, but these have no discernible ideological effect on the source's theme of the lone willow as the poet's heart. 'Marko's hunting with the Turks'

26 Sometimes it is hard to distinguish an alteration from a deletion+addition (e.g. plaited could also be seen as an antonymic alteration from unravelled). But either way, the change will be marked.

27 The Ballads of Marko Kraljević (Ludlow, 2007), p. 146. 
retains most source-poem items, with few changes; and though Low's archaizing style positions the translation as a classic ballad, this echoes the epic's status in the source culture. In contrast to Low's version, however, Bowring's version of the same epic (first published in 1827 but web-posted on Wikisource in 2007) was marked as ideologized, as in the extract below:

\author{
Marko and ['s hunt with] the Turks \\ .. \\ To the proud vizier said princely [Prince] Marko: \\ "Vizier Amurath! is it allow'd me \\ To let loose my own, my favorite falcon? \\ He a gold-wing'd duck shall doubtless bring [eatch] thee.' \\ And the Moslem [Vizier Murat] swiftly answer'd Marko [him].
}

In the poem, the vizier unjustly injures Marko's falcon; Marko furiously decapitates the vizier and his bodyguards; finally, the sultan pays Marko handsomely 'to get him out of his sight'. Bowring changes Marko's patronymic 'Kraljević' ('Prince') to the positive attribute 'princely', thus belying Marko's savage unruliness. The vizier, by contrast, gains the orientalizing attribute 'proud', and becomes 'the Moslem' - a word that occurs nowhere in the source poem. In this way, the violently knockabout subversiveness of the original changes to an orientalist opposition (underscored by the removal of 'hunt with' from the title) between a noble West and an unbending Islam.

How frequent is such ideologizing? Seven of the forty-three projects sampled (16\%) contained at least one poem identified as ideologized; 6/50 named translators (12\%) had at least one translated poem identified as ideologized; and 11/143 sampled poems (8\%) were identified as ideologized. These figures must, of course, be treated with caution. Sampling might have missed some ideologized poems at project level. At translator level, significant under-reporting of ideologizing is less likely: most non-ideologizers retained most sourcepoem meanings, giving no space for ideologizing, and (as mentioned earlier) individual translators did not vary their approach. Moreover, these figures echo Johnson's finding that textual ideologising occurred with 2 out of 13 English translators $(15 \%)$ of Neruda's epic poem Canto general. ${ }^{28}$ At poem level, fuzzy sampling methods make the percentage less trustworthy, though ideologizing may equally well be under- as over-reported. It is safest, therefore, to say that textual ideologizing occurs in relatively few cases - even in this ideologically highly-sensitive publishing context. It does sometimes occur, however. It is thus worth investigating how and why translators ideologize, and fail to ideologize.

Interestingly, no stylistic changes were marked as ideologizing. The only stylistic changes identified were along the archaizing-modernizing axis: there were no markedly regional source poems, and translators recreated a poem's (in)formality or degree of idiosyncrasy fairly closely. Some translations, all produced before the 1930s, were archaized: several bardic-epic translations, and Elizabeth Christich's translation of the Serbian national anthem (analysed semantically below). This, however, simply underlined the source's status as folk ballad or anthem. Other translators modernized the folk diction of the bardic epics, but this also left their ideological message and cultural status unchanged. Though both archaization and modernization of folk epics can be seen as adaptation towards target-culture norms (pre-1930s and later respectively), there is no support in this dataset for Venuti's thesis that this imposes a different, target-culture oriented reading of the poem. Semantic

28 Penelope Johnson, 'Translation and the Image of the Other: The English Translations of Pablo Neruda's Canto General' (unpublished doctoral thesis, Newcastle University, 2010). 
ideologizing, by contrast, does occur. But why is even this infrequent? On close inspection, the outcome appears to depend on the interaction of four variables: poetic form; poem topic; prevailing translation norms; and how individual translators exploit semantic creativity. These are explored below.

The first variable is whether translations use fixed form or free verse. Of the target poems sampled, a substantial fixed form minority recreate or reflect a source poem's rhyme scheme and/or rhythm; these also show large-scale semantic additions, deletions, and alterations. Ten of these poems were marked as ideologizing. As they comprise ten of the eleven ideologized target poems, translating into fixed form appears to be an important precondition for ideologizing. One example is Bowring's 'Marko and the Turks' above. Another is Vasa Mihailovich's 1994 version of Jovan Dučić's rhymed 'Večnoj Srbiji' ('To Eternal Serbia') - a poem written during the ethno-nationalist bloodletting of World War II, which claimed the lives of many Serbs. ${ }^{29}$ Additions allow reproduction of the source's twelve-syllable lines and $a b a b$ rhyme scheme while avoiding semantically empty padding. Some of these additions ('lies', 'lurking', 'glorious' in the extract below) intensify the source poem's ethno-nationalist message; hence the translation was marked as (borderline) ideologizing:

Bog neka te spase tvojih spasilaca,

Na svakome uglu ima ih po jedan.

Prezri mudrost glupih i glupost mudraca!

Nož tvog izdajnika biće uvek žedan.

Kao grom ćeš naći svoga puta.

May God save you always from your saviour's lies,

For on every corner there's one of them lurking.

Despise the fool's wisdom and folly of the wise.

The knife of your traitor will be always be thirsting.

Like thunder you will find your glorious path again.

The creative adaptations and transformations needed to keep fixed form, therefore, can intensify the source's ideological subtext. Less frequently, this subtext may become downplayed, or replaced with a different one. The most radical example of the latter is Christich's 1919 version of the Serbian national anthem 'Bože pravde' ('God of Justice'), as shown in this extract:

Iz mračnoga sinu groba,

Srpske krune novi sjaj,

Nastalo je novo doba,

Novu sreću, Bože daj!

On [From] our [dark] sepulchre of ages

Breaks [Flash] the resurrection morn [Serbian crown's new brightness],

From the slough of direst slavery [New age appear]

Serbia [happiness] anew is born [God give].

Christich's introduction of Christian hymn-phrases such as 'sepulchre of ages' and 'resurrection morn' instead of 'the Serbian crown's new brightness' makes the translation

29 In Aleksandar Petrov, Manje Poznati Dučić/A Less Known Dučić, translated by Vasa D. Mihailovich (Belgrade, 1994; reprint Pittsburgh, PA, 2000), pp. 26, 64. 
more religious and less royalist than the source (although she removes 'God give' in line 4, the increase in religious imagery in lines 1-2 is more typical of the whole poem). Christich wrote original works about Catholic doctrine and women's suffrage: her religious beliefs appear to have influenced this translation, but it is tempting also to see the effects of an antipatriarchal mindset in her downplaying of the source's royalism. Christich also explicitates Serbia's independence as freedom after Ottoman tyranny (here, altering line 3's literal 'A new age has appeared' into 'From the slough of direst slavery'). This was also marked as ideologizing. 'The Ottoman yoke' is a common nineteenth- to early-twentieth century trope for Turkish rule in the Balkans - orientalizing, in that it defines the Ottomans as absolutely other, ignoring the complexities of real-life experience (when Ottoman rule ended in Bosnia, for example, many Bosniaks emigrated to Turkey, fearing what the future might hold).

Fixed-form translations do not necessarily ideologize, however. 'A prosperous year', Ranka Kuić's version of Desanka Maksimović's 'Rodna godina', shows large-scale creative adaptations and transformations: ${ }^{30}$

Duva septembarski mesec u frulu tanku, obrazi mu došli rumeni i puni, zriče zrikavac čokotu u kruni, za gudalo mu zadenuli banku.

The September moon is playing [blow] on [inte] her pipe so long [stim], Her [tts/His] cheeks have become all ruddy and round [full];

A cricket is chirping in a vine-ground [erown],

Someone [They] thrust a coin [10-dinar coin] into his fiddle [bow] for his song.

Some changes explicitate what Kuić judges might be unfamiliar to an English-reading audience: for instance, that line 4 (literally, 'They've thrust a 10-dinar coin into his bow') alludes to how customers pay Balkan café musicians to play a song. In Serbian, 'moon' ('mesec') is grammatically masculine, so line 1's alteration of ['Its/His'] to Her might initially seem to show a feminist ideological drive. However, Kuić is almost certainly following the anglophone convention of personifying the moon as female: 'his cheeks' would be cognitively disturbing, and she retains 'his' for 'cricket'. Otherwise, creative changes simply transform surface details while keeping to the underlying image, making the 'full' moon 'round', for example. They impose no ideological viewpoint.

As for free verse translations, they rarely ideologize, because they rarely deviate enough from source semantics to allow any change in point of view. Matija Bečković's free verse source poem excerpted below, for example, likens the strident ethno-nationalism of the late 1980s to a wolf (the ancient Serbs' totem animal) killed by trying to lick its own blood from a dagger. Ann C. Bigelow renders it into English free verse with very few semantic changes, which offer little space to change, downplay, or heighten the source's cosmopolitanist, anti-war ideology: ${ }^{31}$

Kakvi li su tek ljudi

Pa i čitavi narodi

A pogotovu naš

Koji su vlastite krvi

Ne može nadostiti

30 Don't Fear: Selected Poems, translated by various translators (Belgrade, 1998), pp. 194-5.

31 'Bodež / Dagger', Lyrikline (n.d.) <http://www.lyrikline.org/en/poems/bodez-1916\#.VBmadFeGeFP> (accessed 4 August 2015) 
I pre će nestati

Nego se opsetiti

Da će krvav bodež

Ostati

Jedini

Spomenik

I krst

Iznad nas.

Then what about the people

And even whole nations

[And] Especially ours

That can't get enough

Of our own blood

And would sooner die out [disappear]

Than come to see

That a bloody dagger

Will be all

The monument

And cross

That is left

Above us.

Though Bigelow intensifies 'disappear' into 'die out', this is a small change compared with her close retention of source-text meanings overall. Because these semantic signals generate very similar real-world meanings for source and target readers, her version does not affect the poem's overall message. Moreover, some translators render fixed-form source poems into English free verse. This again usually results in retention-oriented translations, with little space for ideologizing changes.

The only free-verse translation classed as ideologizing was 'Christ our god', a version of the World War I patriotic song 'Hriste bože', a soldier's farewell. This was posted on a web-forum by 'Caesar', presumably the translator, whose avatar picture is a photo of Serbian ethno-nationalist politician Vojislav Šešelj, now on trial for 1990s war crimes: ${ }^{32}$

Zbogom prvi nerođeni sine,

Zbogom ružo, zbogom ruzmarine,

Zbogom leto, jesen i zimo,

Odlazimo da ih pobedimo.

Goodbye my first [unborn] son,

Goodbye my rose, my eternal love [resemary],

Goodbye summer, winter and fall,

We are going [leaving] to win the Turks [them].

The source lines quoted here, as posted by Caesar, are themselves ethno-nationalized, with line 4's original 'Odlazimo da ne vratimo' ('We are leaving not to return') replaced with 'Odlazimo da ih pobedimo' ('We are leaving to defeat them'). The translation, however, defines the enemy ('to win the Turks') where the source leaves the name open. This

32 'Poetry: Serbia', GreekRealm.com (2007), post $10<\mathrm{http} / / /$ www.greekrealm.com/forum/general-talk/1631poetry-serbia.html> (accessed 4 September 2009, now offline) 
explicitates the source song as revenge for defeat in the 1389 Battle of Kosovo, an event frequently evoked in modern ethno-nationalist constructs setting the Serbian 'we' against the Moslem (Bosniak or Albanian) other. The underlying impetus for Caesar's semantic changes, including his ideologizing changes, is not target-poem form, however, but explicitating what he interprets as the source's implicit meaning - as also shown by his explicitation of 'rosemary' into 'eternal love'.

The content tags of the ideologized source poems reveal a second precondition for ideologizing. These are: 'Political / ethno-nationalism, patriotism, cosmopolitanism', and the new tag 'royalism', plus: 'Social/cultural / cultural-history, war-WWII'. The ideologized poems tagged with 'cultural-history' are epics, bardic or non-bardic, telling of pre-modern Serbian-Turkish conflict - a key element in recent Serbian ethno-nationalist narratives, as just mentioned. These narratives also refer to World War II, equating modern Croatian ethnonationalism with 1940s Croatian fascism, and modern Serbs with the latter's victims; cosmopolitanist narratives, however, cite World War II's internecine horrors as an argument against ethno-nationalism. Both aspects are referenced in ideologized poems with 'warWWII' tags. All ideologized source poems, therefore, give clear signals of sociopolitical ideology. No translators ideologized poems carrying other clear sociopolitical signals, such as 'feminism', though this may be because none of the latter were written in fixed forms.

Conversely, though ideology arguably permeates every aspect of life, it is less salient in source poems with non-sociopolitical topics - poems, for example, tagged as 'Poetry-asliterature/miscellaneous', like 'A willow by the sea' or 'A prosperous year' above. None of these were ideologized, almost certainly because very radical intervention would be needed to change, augment, or enhance a source ideological content that is at most very subtle. Moreover, 'miscellaneous' is by far the commonest poem-content keyword, occurring in thirty-one projects, whereas the highest-scoring 'political' tags ('patriotism' and 'ethnonationalism') occur in just five projects each.

A key reason for the low incidence of ideologizing translations, therefore, is that relatively few translations meet the combined preconditions of fixed target form plus salient socio-political source content. Moreover, even these combined preconditions cannot wholly account for textual ideologizing: several translations which met both were not marked as ideologized. An example is Holton and Mihailovich's version of an untitled bardic epic: ${ }^{33}$

Car Murate u Kosovo pade; kako pade, sitnu knjigu piše, te je šalje ka Kruševcu gradu, na koljeno srpskom knez-Lazaru:

'Oj Lazare, od Srbije glavo, nit'je bilo, niti može biti:

jedna zemlja, a dva gospodara.'

On Kosovo Tsar Murad descended [fell].

As he arrived [fell], he wrote a brief letter.

and he sent it to Kruševac city,

to none other than [lap of] the Serb knez, Lazar:

'Oh you Lazar, you leader [head] of the Serbs!

It's never [not] been and [nor] it never will be,

that there can be one kingdom [eountry] and two rulers.'

33 Milne Holton and Vasa D. Mihailovich, Songs of the Serbian People (Pittsburgh, PA, 1997), p. 134. 
The translators' decision to keep the source poem's 4+6-syllable metre means that they have to change semantic details (e.g. from 'Lazar's lap' to 'none other than Lazar'). This adds no ideological element, though the source poem has the same ideologically salient theme of medieval Turkish-Serbian conflict as some ideologized translations.

Further factors, therefore, must also operate. One possibility is that pre-contemporary translators followed older relation norms, which laid less stress on semantic closeness. Three of the eleven ideologizing translations were indeed produced in or before the 1930s: Bowring's orientalizing 'Marko and the Turks' and Christich's more religious but less royalist 'God of Justice' are two. The other eight are roughly contemporary with the database's 1992-2008 time-span, however. Conversely, Helen Rootham's fixed-form versions of the Kosovo epics, first published in 1920, are not ideologized. ${ }^{34}$ Changing norms, therefore, probably constitute at most a minor additional factor.

The only remaining factor appears to be variation between, and within, individual translators when translating poems that meet both preconditions. Some translators use their form-driven semantic freedom more conservatively, making concepts explicit without intensifying attitudes, abandoning only the non-essential, choosing longer or shorter words that only minimally affect source imagery, etc. This leaves the source's ideological message roughly intact, as with Holton and Mihailovich's 'Car Murate u Kosovo pade'. Other translators embrace this freedom more enthusiastically, enhancing or radically changing the source imagery or message - thus increasing the likelihood that, with socio-politically salient messages (as in Christich's 'God of Justice'), these changes may ideologize. The distinction between conservatives and enthusiasts may be a very narrow one, however: Mihailovich's conservative, non-ideologizing collaborative versions with Holton, for instance, differ from his more enthusiastic, ideologizing solo versions of Dučić's patriotic-ethno-nationalist verse. Caesar's four sampled translations provide another example of within-translator variation. Though all make unmotivated or 'explicitating' changes to patriotic-ethno-nationalist source poems, just one poem was classed as ideologizing.

So how does this picture of textual ideologizing, as a relatively infrequent phenomenon driven by a combination of source content, target form, and translator attitude, relate to how a project's structural aspects may communicate ideology? The dataset provides no quantitative evidence of links between the two. For instance, there is no clear relationship between presence $v s$ absence of textual ideologizing on the one hand, and paratext tagging with 'Political / ethno-nationalist or cosmopolitanist' $v s$ 'Poetry-as-literature / poems or poet(s)' (two extremes on a scale of overt socio-political commitment by the team) on the other hand. Moreover, qualitative inspection suggests at most a weak relationship between textual and structural evidence of team ideology. The main argument against such a relationship is that teams with a clear sociopolitical commitment, as shown by paratexts, publishing context, and source-poem content, do not necessarily use ideologized translations. Very often this is because the source poems present no challenges of poetic form, making semantic change unlikely, as with most Pro Femina poems. Second, this is because using creative transformations in poems with salient sociopolitical content need not ideologize. The transformation may have just stylistic effects, for example the emulation of wordplay.

Third, some projects simply republish existing translations. Many of these are older, out-of-copyright translations, which (as mentioned above) may be slightly more likely than newer translations to ideologize. Nevertheless, there is no evidence that even the most politically radical republishers (e.g. ethno-nationalist web forums like Stormfront.org) consider whether translations are ideologized: availability seems enough. Thus Stormfront's

34
<http://home.earthlink.net/ $\sim$ markdlew/SerbEpic/index.htm> 
out-of-copyright bardic-epic translations are mainly non-ideologizing. The only exception is a version of 'Gorski vijenac' ('The Mountain Wreath') by Petar Petrović Njegoš, princebishop of Montenegro: a dramatic epic from 1847 which describes how a forebear of Njegoš reluctantly decided to massacre the inhabitants of a Moslem border village. The translation initially downplays the fierceness of Njegoš's rhetoric, though later changes strengthen the ethno-nationalist message. ${ }^{35}$

These examples show how the content of source poems is more important in promoting a team point of view than how they are translated. This, however, may indirectly affect textual ideologizing: if a team wishes to convey a socio-political stance by selecting suitable fixed-form poems, this makes it more likely (though by no means certain) that the translations will be ideologized. Moreover, where ideologizing does occur, it tends more often to intensify an existing message than to reduce or transform it. This suggests that, if an enthusiastically creative translator joins a team that has selected poems (or selects them her/himself) for an ideological purpose, other team members would be unlikely to object to an ideologizing translation that subtly intensifies this purpose. Manje Poznati Dučić / a Less Known Dučić, which contains 'To eternal Serbia' cited above, is perhaps an example of this. Here the translator's intensifying approach does not go against the orientation expressed in editor Aleksandar Petrov's introduction: ${ }^{36}$

the war raging in Yugoslav lands today is partially a consequence of [how] the communist regime dealt with the Serbs, drawing boundaries which divided the Serbian ethnic body in such a way as to make it very vulnerable to victimization by the descendants of those who had previously conquered and persecuted them.

The 'conquerors and persecutors' refer almost certainly to Moslems and Croats, and thus the ethno-nationalist narrative of Serb victimhood within Yugoslavia.

There may be other, more subtle links between the degree of textual ideologizing and the team's purpose. If the team's purpose is to avoid overt ideology, a non-ideologizing translation may facilitate this by presenting the source poetry as 'simply poetry' - as in the 1998 collection, quoted above, which celebrated the poetic life of Desanka Maksimovic (1898-1993). That this may still be ideological was shown in the 2010 analysis. Here, significantly more Serbian than Bosnian projects were tagged with 'Poetry-as-literature / poet(s) or poems', thus appearing 'to retreat from an ideologically polarized or potentially violent public environment into a private space of pure literature'. ${ }^{37}$ This could be seen as a refusal either to confront the violence endorsed by Serbian state politics of the 1990s, or to be conditioned by Balkanist or pariah-state stereotypes.

A team's poetry-as-literature orientation may also aim to internationalize a local literature: here, to use the global status of English to promote Serbian poetry internationally. The underlying assumptions, that 'our poetry' should be read in the wider world, and will act as a good ambassador for 'our culture', are still ideological in the sense defined earlier. And the translator's choice of an approach focused on semantic and stylistic proximity, where any creative transformations are conservative rather than enthusiastic, may serve this aim well. This concurrence of team aim and translator approach almost certainly underlies the singlepoet and multi-poet books and websites of Serbian poetry, produced in Serbia and with

35 James W. Wiles' 1930 translation, uploaded by 'Iron Cross', post \#43, 'Stormfront.org' (n. 13).

36 Petrov, Manje Poznati Dučić (n. 30), p. 45.

37 Jones, 'Poetry Translation, Nationalism and the Wars of the Yugoslav Transition', p. 23. 
largely Serbian native-speaker translators (or a mix of Serbian-native and Anglo translators) that form a large part of the database.

To sum up, textual ideologizing happens relatively infrequently in this survey. This is because it seems to require a specific combination of circumstances: translators who enthusiastically seize the opportunities for semantic change offered by making fixed-form or explicitating versions of poems with salient socio-political content, with the period's prevailing relation norms as a possible conditioning factor.

This survey samples translations of poetry which were produced in one sociohistorical context. Surveys of other genres and contexts might well modify these findings Nevertheless, this context is ideologically highly sensitive. It is one of civil conflict and its aftermath, where poetry is involved in narratives of cultural identity, and where sourceculture-oriented teams use translation not just to promote a source writer or his/her literary culture internationally (as with most poetry translation worldwide), but also to engage in debates around identity, politics, social equity, and international image. This means that the purpose of Serbian-English translation projects is rarely non-partisan; and in a substantial minority of cases, their purpose is informed by explicit socio-political ideologies, such as cosmopolitanism or ethno-nationalism. Though this is reflected in Serbian teams' choices of project title, project placement, poem content, and paratexts, it is reflected much less strongly and much less consistently in the textuality of the translated poems - a phenomenon that echoes Munday's finding for translations of political speeches. ${ }^{38}$ If textual ideologizing is relatively uncommon even in such an ideologically charged context, therefore, it would be surprising if other, less ideologically charged contexts were to show more textual ideologizing.

The findings also imply that organizing and producing a poetry translation project is a different act, with different rules, from actually translating poems. The aim of communicating a source poet, poets, or poetry to the wider world virtually always underlies both the project team's actions and the translator's translating practice. A team, however, may also have other aims: to promote a point of view about the source literary culture, for instance, or a sociopolitical stance. There is no ethical bar on furthering these aims by, for example, posting the poems on a certain website, giving the publication a certain title, or stating the aims in an editor's introduction. However, there are ethical objections to promoting these aims by consciously changing the translated text: the ethic of loyalty to a source poet, and to target readers who expect a fair representation of a named source poet's text.

In virtually all the poems in this survey, including all those marked as ideologizing, the translators appeared driven by one or both of these ethics. Ideologizing, for instance, usually occurred when the ethic of faithfully representing source semantics conflicted with that of faithfully representing source poetics - with ideologizing translators opting for poetics rather than exact meanings, while representing their interpretation of the poet's best interests by making what they felt was an effective target-culture artefact (a singable English anthem with Christich's 'God of Justice', for instance). The only exception here is 'Caesar', whose ideologizing stems simply from the wish to make explicit - perhaps because he is an amateur, who has not internalized the translators' norm that permits semantic disloyalty only if it enables poetic loyalty. However, explicitating a message that translators perceive in the source poem also underlies most cases of form-driven ideologizing. As explicitation appears to be a 'universal' tendency of translators, ${ }^{39}$ it is perhaps unsurprising that it can also create space for ideologizing explanations.

38 Jeremy Munday (2007) 'Translation and Ideology: a Textual Approach', The Translator, 13 (2007), 195-217.

39 Van Leuven-Zwart (n. 5), Part II, p. 89; Chesterman (n. 7), p. 71. 
Moreover, most ideologizing changes were 'gradual', i.e. they modulated messages already in the source poem - usually enhancing them, which implies that translators did not object to the source ideology. Few changes downplayed or (as with 'God of Justice') 'oppositionally' altered source ideologies, which would imply translators' unease with the latter. ${ }^{40}$ When source ideologies are left intact (as in Pro Femina), without translators' reports one cannot tell how far this is because translators are following the ethic of loyal representation, and how far because they agree with source-poem ideologies; however, as poetry translators usually work on projects they believe in rather than for money, there is probably a virtuous overlap here.

This study cannot show how far ideologizing and its avoidance is deliberate and how far inadvertent. Other studies show how poetry translators can describe their practice as driven by an ethic of loyalty to the source poet or of giving readers a fair representation of the source poem. This representation, of course, is based on the translator's individual interpretation of the source poem's text-world and 'message' from semantic and stylistic clues, which can be influenced by his/her ideological make-up. ${ }^{41}$ Though this subjectivity of interpretation almost certainly influences whether translators ideologize or not under the right textual preconditions, I suspect that it usually operates below the level of consciousness. My own experience suggests, however, that translators become aware of these issues when they feel that an ideologically driven solution might conflict with the ethic of fair representation, even if they decide in favour of the former. ${ }^{42}$ In any case, no value judgement should be attached to ideologizing or non-ideologizing approaches per se. Value judgements, in my view, should be reserved for the potential of ideologies themselves to do good or harm - be they the ideologies of the source poems, those modified by the translator, or those promoted by the project team.

Finally, the low frequency of textual ideologizing suggests that the case studies mentioned earlier do indeed describe the interesting but exceptional. It does not contradict the assumption that textual ideologizing is inherent in literary translation. This study has found enough examples of it to show that it can indeed happen, and for reasons inherent in poetry translation: the relationship between textual form and content, for instance, and different translators handling this relationship differently. However, it does strongly suggest that any model of literary translation and ideology needs to incorporate not only how and why some translators modify a text's ideological stance, but also why most translators do not.

University of Newcastle

40 'Gradual' vs 'oppositional': Van Leuven-Zwart, Part II, p. 70.

41 Jones, Poetry Translating as Expert Action, pp. 178-81; Robert Bly, The Eight Stages of Translation (Boston, MA, 1983); Ruth Feldman, 'On Translating Italian Poetry', Forum for Modern Language Studies, 33 (1997), 3-16; Jean Boase-Beier, 'Knowing and Not Knowing: Style, Intention and the Translation of a Holocaust Poem', Language and Literature, 13 (2004), 25-35.

42 Though in the present study I belong to the non-ideologizing $88 \%$ of translators, I am aware of having adopted an ideology-driven solution in another context: see Francis R. Jones, 'Ethics, Aesthetics and Decision: Literary Translating in the Wars of the Yugoslav Succession', Meta, 49 (2004), 711-28 (p. 720). 